\title{
ERJ
}

Engineering Research Journal

Faculty of Engineering

Menoufia University

\section{Investigation of Combustion and Emission Characteristics of Diesel/Bio- Diesel Blends under Oxygenated Fuel Burner.}

\author{
E. A. El-Shenawy, Medhat ElKelawy, Hagar Alm-Eldin Bastawissi, Mahmoud Al-Hofy.
}

Department of Mechanical Engineering, Faculty of Engineering, Tanta University, Egypt.

\begin{abstract}
:
The study of the flame characteristics and emissions of oxy fuel combustion of diesel and diesel biodiesel blends is performed using an experimental test burner manufactured for this reason in a laboratory scale. The fuels used are the conventional diesel fuel and a mixture of diesel and bio-diesel (B0, B10, $\mathrm{B} 20$, and $\mathrm{B} 40$ ) when the number refers to the bio-diesel percentage in the blend, In this present paper the behavior change of $\mathrm{CO}, \mathrm{CO} 2, \mathrm{HC}$, and $\mathrm{NOx}$ emissions was investigated for the selected blends with the increasing of oxygen concentration gradually by an oxygen cylinder to the air consumed in combustion. The flame characteristics (cone angle, flame length and appearance) also studied with the oxygen concentration change. It was observed that the carbon monoxide, carbon dioxide, unburned hydrocarbons, NOx, and the temperature are higher in diesel than bio-diesel blends in air combustion and in oxy- combustion. This may because the number of hydrogen and carbon atoms is more in conventional diesel than bio-diesel, also the calorific value, so the temperature is higher. The flame cone angle and flame penetration length decreased after the addition of oxygen and bio-diesel, this is due to the presence of sufficient amount of oxygen which causes early chemical reaction between the fuel and oxidizer. By using oxy fuel combustion of renewable sources we can save money spent in conventional petroleum fuel.

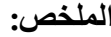

$$
\begin{aligned}
& \text { يهذف هذا البحث لدراسة خصائص اللهب والإنبعاثات الناتجة من احتراق وقود الديزل التقليدي ومخاليط من وقود الديزل والبيوديزل } \\
& \text { (B0, B10, B20, B40) }
\end{aligned}
$$

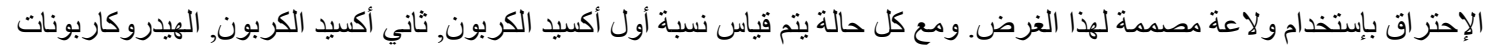

$$
\begin{aligned}
& \text { الغير محترقة, الأكسجين و أكاسيد النيتروجين و الدخان (الهباب) وذلك باستخدام جهاز لتحليل العو ادم, ويتم أيضا دراسة خصائص اللهب }
\end{aligned}
$$

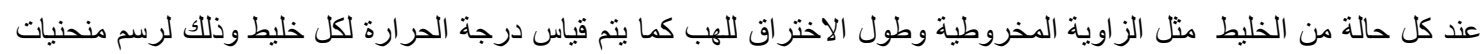

$$
\begin{aligned}
& \text { التغير للنتائج وسهولة الدقارنة بينها. وقد لوحظ أن قياسات أول وثاني أكسيد الكربون والهيدروكاربونات الغير محترقة وأكاسيد }
\end{aligned}
$$

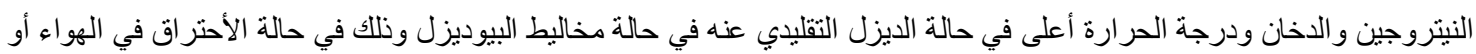

$$
\begin{aligned}
& \text { مع اضافة الأكسجين ويرجع ذلك الى زيادة عدد ذرات الكربون والهيدروجين وارتفاع القيمة السعرية (CV) للايزل عنه في البيوديزل }
\end{aligned}
$$

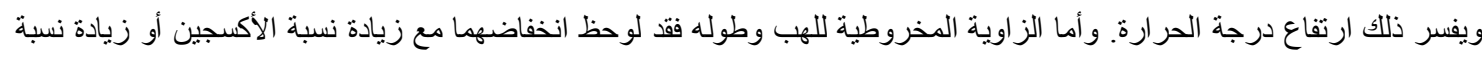

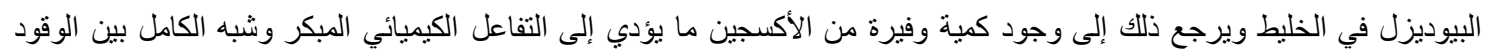

$$
\begin{aligned}
& \text { و المؤكسد. وبإستخدام الوقود العضوي كبديل للوقود البترولي التقليدي يمكننا تقليل النفقات و الحفاظ على البيئة بتقليل الملوثات. }
\end{aligned}
$$

Keywords: Oxy-combustion, Bio-diesel, flame characteristics, NOx emissions, liquid fuel burner.

Symbols and abbreviations:

A/F: air to fuel ratio.

B0: $100 \%$ diesel fuel with 0\% bio-diesel. B40: 40\% bio-diesel.

HC: Unburned hydrocarbons.

NOx: Nitrogen oxide.

\section{INTRODUCTION}

Due to the ever increasing in the energy demands associated with the limited availability of fossil fuels and the harmful effects of air pollutants such as NOx, Sox, and the greenhouse gases which create acid rain, depletion of ozone, and which have a very dangerous effects over public health, the new policies regulations were legalized. And so that the ppm: particle per million.

use of renewable fuel sources of energy such as wind, solar, hydraulic power, or bio-fuels are being promoted by the developed countries governments and the international organizations to gradually substitute conventional fuels by alternative ones.[1] Oxy-combustion is considered one of the important options for the carbon dioxide capture from the power generation plants which fired with the fossil fuels. However, there are some noticeable 
difficulties of using the oxy-fuel combustion new technology, the main one is the high cost which associated with the producing of the high purity oxygen by the cryogenic distillation process [2]

The chemical reactions of the direct transformation of oils (vegetable oils) into methyl esters are known for more than a century. This reactions which of interest today, mainly the reactions producing methyl esters from soybean, rapeseed, and the sun flower oils, have been carefully studied and developed in order to manufacture high quality diesel fuel which known as bio-diesel[3].

There are a number of methods and techniques which have been performed for gaseous emissions reduction such as NOx, Sox and $\mathrm{CO} 2$ produced from the combustion of fossil fuel and for reducing the costs associated with these techniques[4] Some of these methods are expensive and as a result increase the production cost. Co-firing is one of the less expensive solutions, which gained popularity with electric power producers [5]

Nowadays, bio-fuels have received escalated attention due to the attractive features of being from renewable sources and because it reducing the net carbon dioxide emissions. Also the carbon dioxide (CO2) emissions can be reduced by adding oxygen to the bio-mass[6]. During the oxy-fuel combustion, the fuel is burnt with oxygen and recycled flue gas in order to get a rich $\mathrm{CO} 2$ (about 95\%) and a water vapor stream which is ready for sequestration after the purification and compression[7]. an important advantage of this technology is that it avoids the formation of thermal NOx due to the nitrogen gas absence in the combustion atmosphere, with the result that $\mathrm{NOx}$ emissions are reduced[8].

The formed NOx emissions are mainly due to three mechanisms which involved during the combustion reaction, they are thermal NOx, fuel NO, and the prompt $\mathrm{NO}$ [9]. Bio-fuels are considered environmentally friendly for several reasons. First, there is no net increase in $\mathrm{CO} 2$ as a result of burning a biomass fuel (i.e. fossil generated $\mathrm{CO} 2$ ). Biomass consumes the same amount of $\mathrm{CO} 2$ from the atmosphere during growth as is released during combustion[1].

It was found that the combustion of bio-mass with coal is a way for reducing the pollutants emissions. For ideal combustion condition, the using of biomass containing low concentration of nitrogen and sulfur and so a high volatile content with smaller heating values is suggested. using bio-fuels in the industrial purposes can also releases ammonia, methane, amides, organic acids and chemical elements which are very beneficial to the environment.[10]

Its well known that sulfur provides the diesel fuel with the lubricity which will disappear when the regulations which restrict the sulfur content in the diesel to a limit of $50 \mathrm{ppm}$, but when adding biodiesel to the diesel fuel by about one to two percentage has the good beneficial effect of restoring the lubricity which maintain the anti wear action and then preventing all the engine injection system[11, 12]. the Oxy-firing combustion is differs from the air combustion in the using of recycled flue gases, and which generate a stream of carbon dioxide with high concentrations, this can lead to the corrosion in boiler tubes as a result to the accumulation of undesirable species[4]. Most previous work achieved in the field of oxy-co-firing was on pulverized coal mixed with solid fuel (biomass) by different amounts $(20 \%, 30 \%, 40 \%, \ldots)$ in air condition and oxy-fuel condition.

In a certain research paper the ignition temperature and the burnout of the combustion of coal were studied under the conditions of oxy-fuel combustion, the reaction was performed in an entrained flow reactor (EFR).

In the results the ignition temperature was to be higher under a $(21 \% \mathrm{O} 2-79 \% \mathrm{CO} 2)$ atmosphere than in the air case, and the burnout was lower. By increasing the $\mathrm{O} 2$ concentration to 30 and $35 \%$ in the oxy-fuel atmosphere, also the ignition temperature was lower than in the air condition, and the burnout was increased above the value reached under the air-firing. Finally, the ignition temperatures were higher and the coal burnout values were lower after the addition of steam in the oxy-fuel combustion case, but there are no observed differences between the different steam concentrations. It was found that the addition of biomass to coal improved the burnout in both the air and the oxy-firing conditions, which reflecting the higher reactivity of biomass[6].

The characteristics of the spray of Biodiesel in an air blast atomizer and by changing the injection pressure are a topic of concern for bio-fuel investigations. The parameters mainly characterize the atomization are spray tip penetration length, sauter mean diameter, the spray cone angle and the open flame structure such as the flame length, flame lift, flame width, and the inflame temperature, it was found that the biodiesel is slightly higher in sauter mean diameter when compared with diesel fuel.

Spray cone angle was decreased with the addition of the biodiesel in diesel fuel, which show that for biodiesel fuel we can use slightly higher pressure for injection to get the same atomization.

As a result of the high viscosity and the surface tension value of the biodiesel the spray tip penetration increases when compared to the diesel fuel. For the case of higher injection pressure and higher atomizing air to fuel ratio, all the fuel tested shows the similar spray characterization such as spray tip penetration length and spray cone angle. As the vol. percentage of the biodiesel increases in the blends, flame length found decreasing as a 
result of the sufficient oxygen which helps for earlier combustion and the flame width are observed to be higher due to the increasing in the spray cone angle.

It was observed that the stability of the flame decreases due to the increasing of biodiesel percentage in the blends and the flame lift lowers with the increasing of the fuel pressure. The open flame temperature is found to be decreasing with the additional of the biodiesel in the conventional diesel fuel due to the lower calorific value[13].

Burner is a device that is used to combust the fuel with the oxidizer (usually air) in a controlled manner to convert the chemical energy in the fuel into thermal energy. As it is known there are several types of burners, the burner design in most cases is optimized based on the choice of the fuel type, there are burners which work with only one fuel and this is the most, the fuel may be CNG, NG coal or oil, the other type is the dual fuel burners, which may be used for economic reasons, in this type there is a possibility to switch between the two different fuels or sometimes the burner can work on both fuels together[14]. One common method for classifying burners is according to how the fuel and the oxidizer are mixed. In premixed burners, the fuel and the oxidizer are completely mixed before combustion begins. Thermal radiation burners and radiant wall burners usually are of the premixed type. Premixed burners often produce shorter and more intense flames, as compared to diffusion flames. This can produce high-temperature regions in the flame, leading to non uniform heating of the load and higher NOx emissions, although this is very dependent on the specific design. However, in flame impingement heating, premixed burners are useful because the higher temperatures and shorter flames can enhance the heating rates[15].

By the experimental tests it was found that Alternative fuels could be efficiently combusted in the industrial burners, for the same operating conditions, the combustion reaction of the liquid butane gets a similar output of energy with fewer emissions than the diesel fuel combustion. Also, with the flame of liquid butane, the temperatures are distributed better through the combustion chamber[16]. In the diffusion-mixed burners' type, the fuel and its oxidizer remain separated and unmixed prior to combustion, which begins where the oxidizer/fuel mixture is within the flammability range (assuming the temperature is high enough for ignition). Oxygen/fuel burners are usually diffusion burners, primarily for safety reasons, to prevent flashback[15].

In the present paper, oxy-combustion is performed for conventional diesel fuel and diesel biodiesel blends using an experimental test burner manufactured for this reason in a laboratory scale. The aim of this research is the investigation of the combustion emissions change and the study of the flame characteristics related to the oxygen concentration consumed in the selected blends combustion reaction.

\section{EXPERIMENTAL SETUP AND PROCEDURE:-}

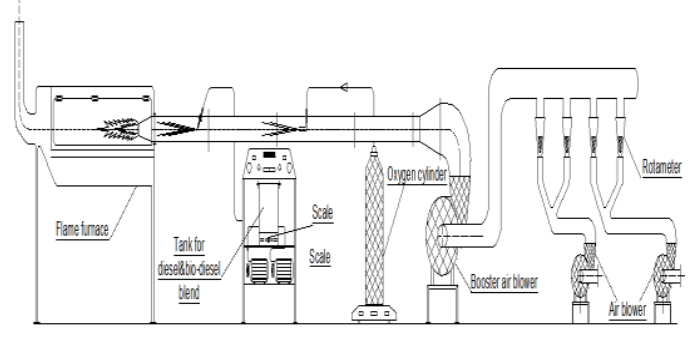

Fig (1). Single line layout for the system component.

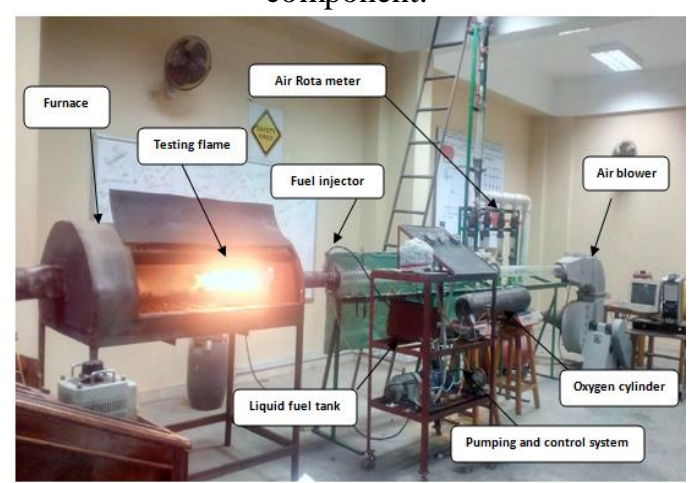

Fig(2). The entire system component during oxycombustion.

As it known, in order to obtain continuous flame, a source of air or oxygen must be supplied.

In this study air is used to complete the combustion process with the addition of a quantity of oxygen to improve combustion efficiency. Theoretically, each one mole of fuel needs one mole of oxygen to get a complete combustion of all the fuel atoms, but to get one mole of oxygen we have to mix one mole of fuel with 4.76 mole of air, as the oxygen mole is presented with 3.76 mole of nitrogen, which is an inert gas and does not share in combustion.

This shows the great importance of the good mixing between fuel and air. In our case, the fuel is pumped to the injector at a high pressure (from 120 to 150 bars) which releases the liquid fuel from the narrow aperture of the injector as atoms introductorily to mixing with air.

The injector is located within the air pipe and fixed by a mean which ensures a central flow of the liquid fuel and is about $80 \mathrm{~cm}$ away from the outlet of the nozzle which mounted in the furnace onset, the air pipe improves the chance of mixing between liquid fuel and air particles coming from the air blower before the firing reaction. 
The air coming out from the air blower is firstly mixed with oxygen exits from the oxygen cylinder. The mixing distance for air, oxygen is about 400 $\mathrm{cm}$ in a transparent acrylic pipe with $11 \mathrm{~cm}$ diameter.

At the end of the acrylic air pipe the metal pipe is fixed, it ends by a nozzle which mounted directly into the furnace. Therefore, all these precautions help to obtain a good spray of liquid fuel with a good mixing between all components.

This experimental test burner enables us to test the combined combustion of different types of fuels (co-firing) or of each type individually, thus obtaining the best proportion of each fuel involved in the mixture to obtain the highest combustion efficiency in terms of thermal output with the lowest proportion of pollutants in the exhaust.

This result can be applied in many industrial applications where a high temperature is requested, or in the field of electric power production replacing the natural gas consumed in steam boilers by bio-fuel sources. In this experiment, all variables can be measured and controlled.

The liquid fuel pressure can be raised up to 600bar (the operating pressure is from 120 to 150 bars) by a system of two high pressure feeding pumps.

In order to control quantity and pressure of the liquid fuel, a returning valve is connected to the discharge line to return a part of the fuel to the tank so that it helps to control pressure. The main line is connected to the accumulator (a cylinder with high thickness to withstand the high pressure) and then to the injector.

The air is obtained by running the air blower operated by a three phase electric motor. This blower pressures the air directly into the air pipe.

Air intake is controlled by opening or closing a number of four ROTAMETER on a fan suction pipe, and Rota meters is used to measure and control the amount of air passed to the burner face, it is measured by a unit of ( $\mathrm{m} 3 / \mathrm{hr})$.

The oxygen is added through an air regulator (in order to control the oxygen quantity) to the air pipe line.

The amount of oxygen added to the reaction is calculated by a stop watch and a digital balance in which the cylinder is placed to determine the amount of oxygen consumed in the oxygen combustion process.

A fuel source must also be continuously supplied to maintain the flame. The fuel flow rate is measured by a stop watch and a digital balance in which the fuel tank is placed.

More than one type of fuels is used in this investigation. The first type of fuel is the conventional diesel oil extracted from the petroleum oil. The second is bio-diesel; the fuels are mixed efficiently by the pumps and the return line (recirculation).

\section{FUEL PROPERTIES:-}

In this research the fuels used are conventional petroleum diesel and a blend of diesel and biodiesel B0, B10 (refer to 90\%diesel and 10\%biodiesel), B20 and B40.

The fuel blends were prepared manually by mixing the two requested fuel amounts on the basic of mass proportion, to ensure good mixing between the two fuels as the viscosity is not the same; the blend was recirculated to the fuel tank by two fuel pumps for a time of 30 minutes.

The bio-diesel was produced from vegetable oil which used in frying by the transesterification method.

Table (1): The properties of the fuels used (diesel and bio-diesel).

\begin{tabular}{|c|c|c|c|c|}
\hline property & $\begin{array}{c}\text { AST } \\
\text { test } \\
\text { meth } \\
\text { od }\end{array}$ & unit & $\begin{array}{c}\text { Diese } \\
1\end{array}$ & $\begin{array}{c}\text { Bio- } \\
\text { diesel }\end{array}$ \\
\hline $\begin{array}{c}\text { Density at } \\
\text { 40C }\end{array}$ & $\begin{array}{c}\text { D405 } \\
2\end{array}$ & $\mathrm{~kg} / \mathrm{m} 3$ & 846 & 930 \\
\hline $\begin{array}{c}\text { viscosity } \\
\text { at 30C }\end{array}$ & $\mathrm{D} 445$ & $\mathrm{cmSt}$ & 3.38 & 5.1 \\
\hline $\begin{array}{c}\text { Calorific } \\
\text { value at } \\
\text { 40C }\end{array}$ & $\mathrm{D} 240$ & $\mathrm{MJ} / \mathrm{kg}$ & 42.47 & 36.01 \\
\hline $\begin{array}{c}\text { Surface } \\
\text { Tension } \\
\text { at 40C }\end{array}$ & $\mathrm{dyne} / \mathrm{c}$ & 26.43 & 29.4 \\
\hline $\begin{array}{c}\text { Flash } \\
\text { point }\end{array}$ & $\mathrm{D} 93$ & $\mathrm{C}$ & 62 & 240 \\
\hline $\begin{array}{c}\text { Sulfur } \\
\text { content }\end{array}$ & $\mathrm{D} 129$ & $\mathrm{wt} \%$ & 0.000 & 60.00 \\
\hline $\begin{array}{c}\text { Pour } \\
\text { point }\end{array}$ & $\mathrm{D} 97$ & $\mathrm{C}$ & -12 & 3 \\
\hline
\end{tabular}


INSTRUMENTS ERROR ANALYSIS:-

Table (2): The accuracy and Uncertainty of the instruments.

\begin{tabular}{|c|c|c|c|}
\hline $\begin{array}{c}\text { Instru } \\
\text { ment }\end{array}$ & $\begin{array}{c}\text { Rang } \\
\mathrm{e}\end{array}$ & $\begin{array}{c}\text { Accuracy } \\
\text { (absolute error) }\end{array}$ & $\begin{array}{c}\text { Uncer } \\
\text { tainty } \\
\% \\
\text { (relati } \\
\text { ve) }\end{array}$ \\
\hline $\begin{array}{c}\text { Gas } \\
\text { analyz } \\
\text { er }\end{array}$ & $\begin{array}{c}\mathrm{HC} \\
\mathrm{CO} \\
\mathrm{CO} 2 \\
\mathrm{O} 2 \\
\mathrm{NOx}\end{array}$ & $\begin{array}{c} \pm 10 \times 10-6 \\
(\mathrm{ppm}) \mathrm{Vol} \\
\pm 0.03 \times 10- \\
2(\%) \mathrm{Vol} \\
\pm 0.5 \times 10-2(\%) \mathrm{Vol} \\
\pm 0.1 \times 10-2(\%) \mathrm{Vol} \\
\pm 25 \times 10-6 \\
(\mathrm{ppm}) \mathrm{Vol}\end{array}$ & $\begin{array}{l} \pm 5 \% \\
\pm 5 \% \\
\pm 5 \% \\
\pm 5 \% \\
\pm 4 \%\end{array}$ \\
\hline $\begin{array}{c}\text { Digital } \\
\text { scale }\end{array}$ & $\begin{array}{c}0- \\
40 \mathrm{Kg}\end{array}$ & \pm 1 gram & $\pm 0.2 \%$ \\
\hline $\begin{array}{l}\text { Digital } \\
\text { stop.w }\end{array}$ & - & $\pm 0.01 \mathrm{sec}$ & $\pm 0.1 \%$ \\
\hline $\begin{array}{c}\text { Pr. } \\
\text { gauge }\end{array}$ & $\begin{array}{c}0-600 \\
\text { bar }\end{array}$ & \pm 5 bar & $\pm 2 \%$ \\
\hline $\begin{array}{l}\text { Rota } \\
\text { meter }\end{array}$ & $\begin{array}{c}0- \\
180 \mathrm{~m} \\
3 / \mathrm{hr}\end{array}$ & $\pm 6 \mathrm{~m} 3 / \mathrm{hr}$ & $\pm 3 \%$ \\
\hline
\end{tabular}

\section{RESULTS ANALYSIS AND DISCSSION:-}

This burner was manufactured in order to investigate the emissions and the flame characteristics of oxy-combustion of diesel fuel and diesel/bio-diesel fuel blends.

1- Carbon monoxide:-

Due to the higher oxygen content of bio-diesel $(10 \%-12 \%$ on weight basis) the combustion improves when compared with diesel fuel, so it was found that carbon monoxide emission decreases with the increasing of bio-diesel quantity in the blends, this is shown in figure 3 .

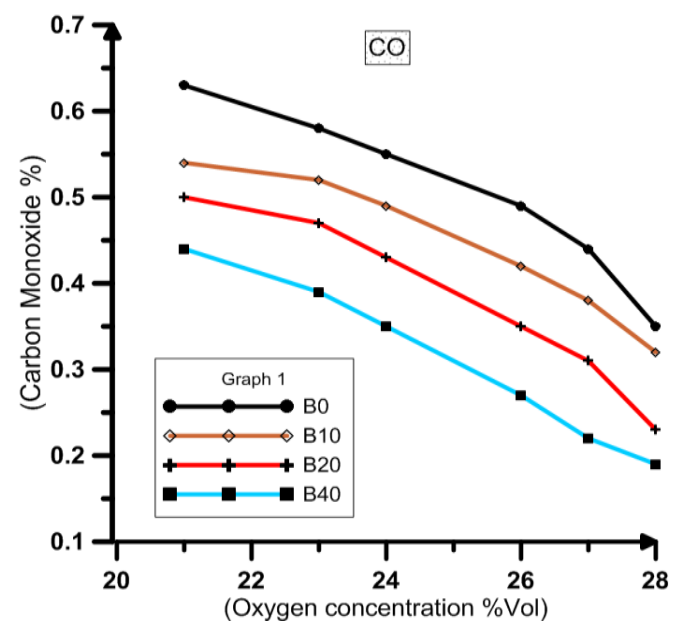

Figure (3). CO change related to the oxygen concentration \%vol

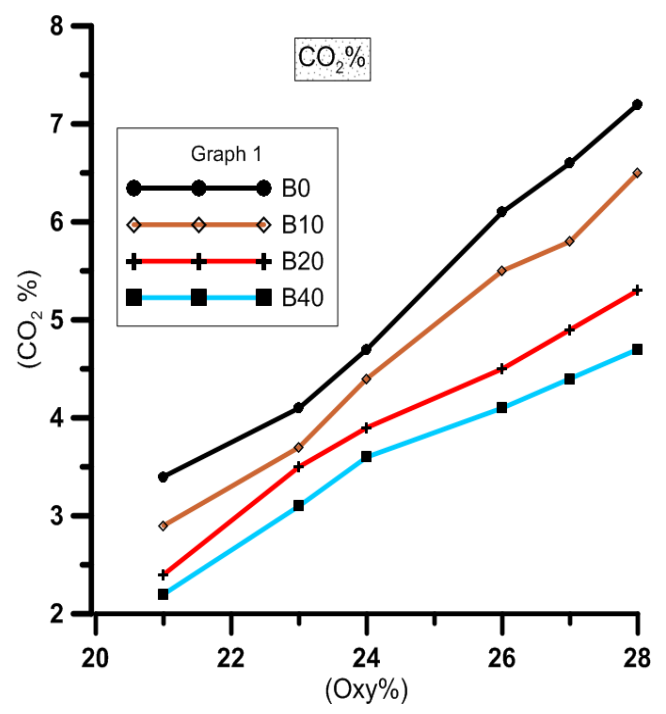

Figure (4). $\mathrm{CO} 2$ change related to the oxygen concentration \%vol.

\section{2- Carbon dioxide:-}

Bio-fuels are renewable sources which can be used to reduce $\mathrm{CO} 2$ emissions. This source of energy is considered carbon neutral because the carbon dioxide released during its combustion is recycled as an integral part of the carbon cycle this is true also with all fuels of biological sources. Theoretically, each one mole of fuel needs one mole of oxygen to get a complete combustion, so that when there is a sufficient amount of oxygen associated with perfect mixing between the atoms of fuel and oxygen the combustion reaction is complete and carbon dioxide increases.

It was observed that $\mathrm{CO} 2$ emission is higher in diesel case; this may be because the number of carbon atoms in diesel is more than the number of carbon atoms in bio-diesel by about $40 \%$, and this illustrates the difference in calorific value between the two fuels. The change of $\mathrm{CO} 2$ with the increasing of oxygen concentration is shown in figure 4.

3- Unburned hydrocarbons (HC):-

The proportion of hydrocarbons found in combustion products indicates how efficient the combustion is, and the experimental results show us that by increasing the oxygen rate the unburned hydrocarbons decreased and combustion improved for diesel and diesel-biodiesel blends, this is shown in figure 5. 


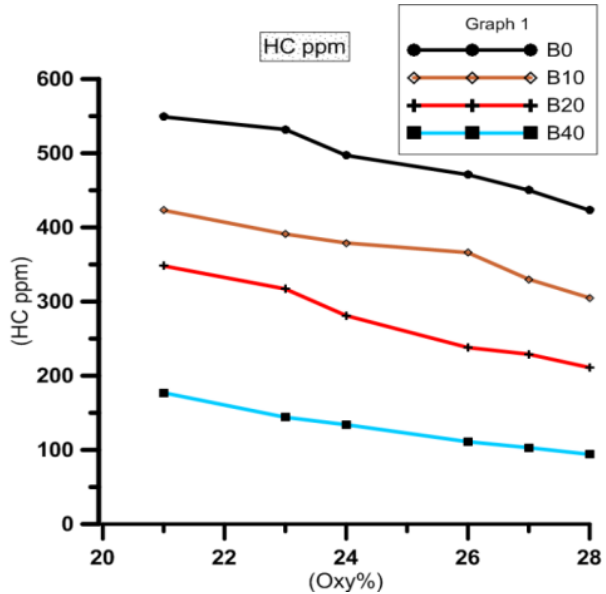

Figure (5). Unburned $\mathrm{HC}$ measurements with the

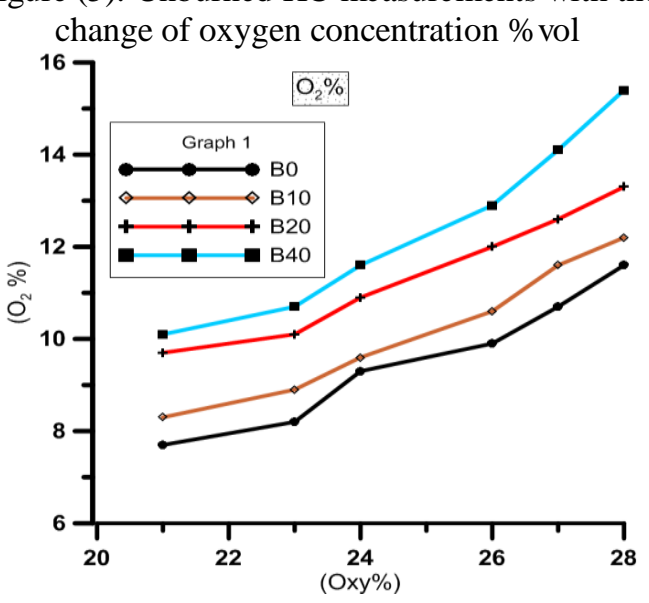

Figure (6). oxygen measurements with the change of oxygen concentration $\%$ vol

4- Oxygen (O2):-

Figure 6 shows the increase in the ratio of oxygen measured by the exhaust analysis device with the increasing of its flow rate during the reaction in each case.

\section{5- NOx emissions:-}

In premixed combustion the fuel and oxidizer are approximately completely mixed before combustion begins, which produces shorter and more intense flame. In this type the flame temperature is higher and then the NOx emission.

The nitrogen contained in fuels and which exists mainly combined with other one component or more such as (H3N, HCN...) can be easily converted to (NOx) as (NO or NO2) by oxidation, and this happened at low temperatures, it's called fuel NOx, furthermore the atmospheric nitrogen (N2) oxidation process happened at high temperatures (more than $1800 \mathrm{~K}$ ), and the product called thermal NOx[4]. High burnout and minimum emission of NOx, SO2 can be achieved in oxy cofiring for biomass with hard coal by controlled injection method in to the burner[17]. In the present work the combustion is premixed and it was observed that by increasing the oxygen rate in the air for diesel fuel the NOx emissions increased this is due to the availability of oxygen and the temperature raising, by adding biodiesel to diesel fuel it was found that the NOx emissions decreased this may be due to NOx is temperature dependant, figure 7 shows the change of NOx (ppm) with the increasing of oxygen concentration for diesel and diesel biodiesel blends.

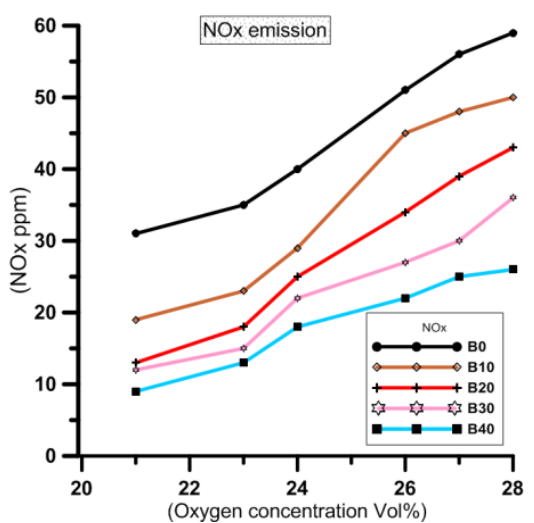

Figure (7). NOx emission change related to $\mathrm{O} 2$ concentration change

6- Smoke opacity:-

The soot is produced as a result of incomplete fuel combustion. The combustion Diesel oil has the biggest soot agglomeration size compared to biodiesel[18].

The international environmental protection agencies emission regulation includes high restriction of particulate matter (PM) and nitrogen oxide (NOx), which cause the forming of the carbonaceous agglomerate (soot). The lower percentage of soot equals to the less carbon release in the atmosphere, and thus reduces the harmful effect on the environment[19]. Figure 8 shows the change of smoke opacity with oxygen concentration.

Soot opacity measured by visual observation of an especial paper as its color changes from clear white to dark black according to the amount of formed soot (color method indicator), this paper is replaced in the beginning of each test run.

It was observed that by increasing the oxygen rate the smoke opacity decreases for diesel and all blends, this is due to the noticeable decreasing in the $\mathrm{HC}, \mathrm{CO}$, and $\mathrm{NOx}$ which contribute in forms the exhaust soot. 


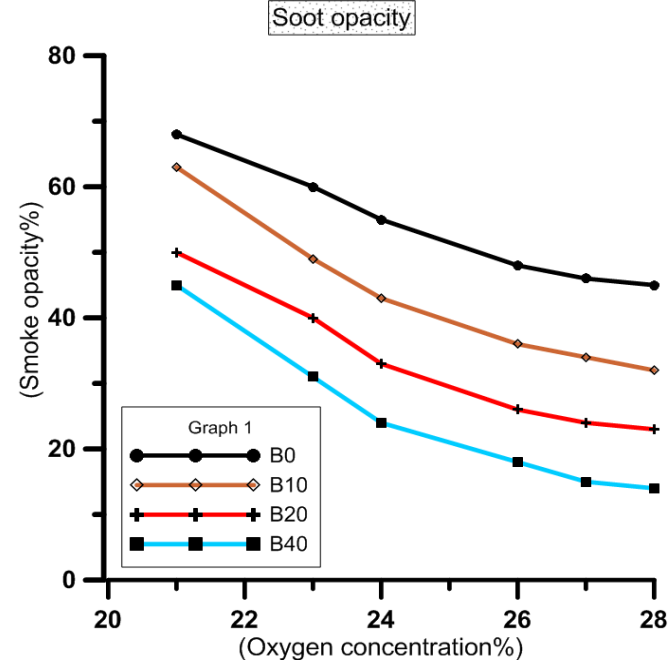

Figure (8). NOx emission change related to $\mathrm{O} 2$ concentration change.

7- Inflame temperature:-

It was observed that temperature increases with the increasing of oxygen concentration for each individually, this may due to the improvement of the combustion, by increasing the percentage of bio-diesel in the blends the temperature decreased, and this may occurs because the calorific value for bio-diesel is lower than diesel. Flame temperature was measured in the second third of the flame and it was measured by thermo couple connected with a microcontroller board (Arduino). The temperature changes with oxygen for each blend are shown figure 9 .

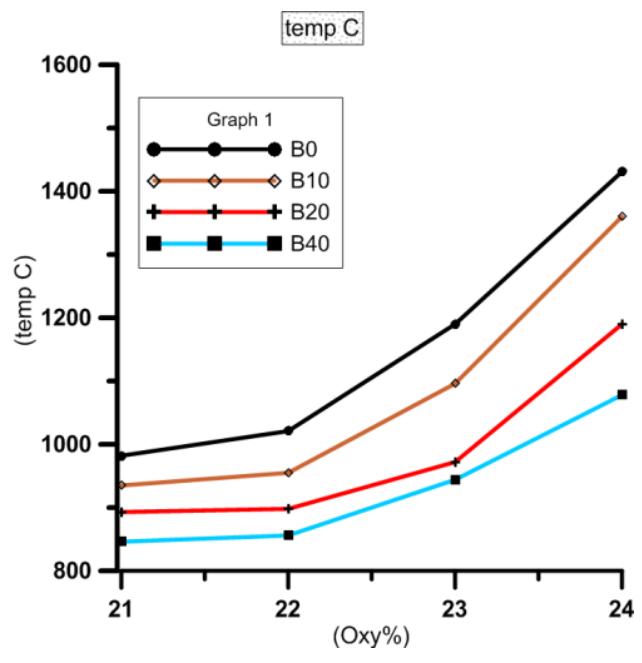

Figure (9). Inflame temperature related O2 concentration change.
Flame geometry:-

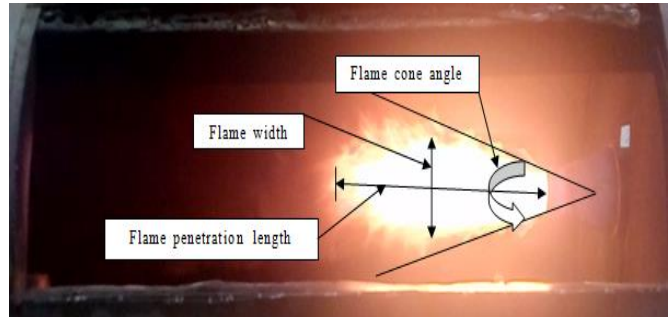

Figure (10). Cone angle, penetration length and the width of the burner investigated flame

In our present case the injector was putted in the burner pipe away from the nozzle exit by about $60 \mathrm{~cm}$, so that the combustion is considered premixed. To investigate the combustion flame geometry the flame cone angle and the flame penetration length are to be measured. The flame cone angle is the angle between the upper and the lower tangents of the flame, and the penetration length is taken as the distance from the first point of the flame at the burner face exit to the end point of the flame. The flame cone angle, the penetration length and the flame width are shown in figure 10.

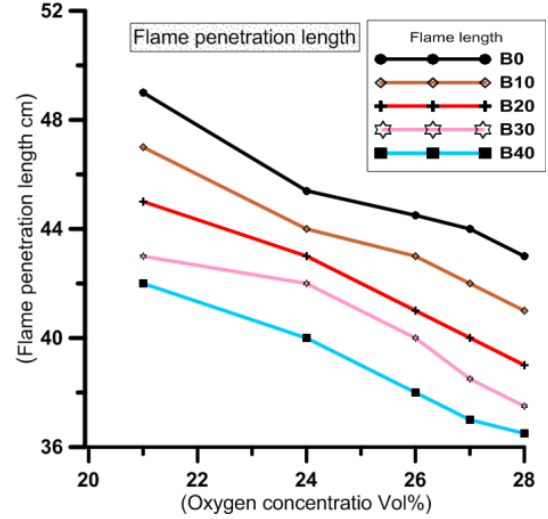

Figure (11). Flame penetration length related with oxygen concentration.

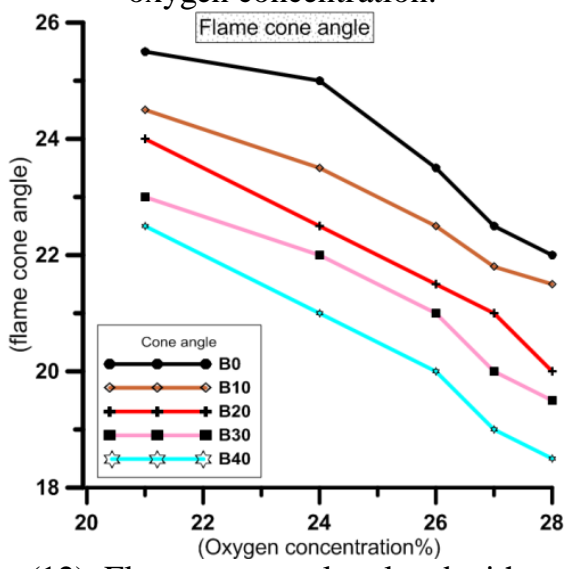

Figure (12). Flame cone angle related with oxygen concentration.

8- Flame penetration length:-

The flame penetration length is the distance from the first point where the combustion begins of the at the burner face exit to the farthest point at which 
the flame vanish. It was found that the flame length decreases with the increase of oxygen percentage, this due to the availability of oxygen which causes early combustion for fuel atoms. The change of the flame penetration length with oxygen percentage by volume is shown in figure 11.

9- Flame cone angle:-

It is observed that, by increasing the oxygen rate sharing in combustion, the flame cone angle decreased in the same fuel case, and it was decreased also when the biodiesel percentage increased. The variation of the flame cone angle with oxygen rate is shown in figure 12 .

Table (3): Images for fuel combustion under different oxygen concentrations

\begin{tabular}{|c|c|c|}
\hline $\begin{array}{c}\text { Blen } \\
\mathrm{d}\end{array}$ & $21 \%$ Oxy & $27 \%$ Oxy \\
\hline B0 & & \\
\hline B10 & & \\
\hline B20 & & \\
\hline
\end{tabular}

\section{CONCOLUSION:-}

The flame characteristics and the exhaust emissions of an oxy combustion are studied.

Conventional petroleum diesel and diesel/bio-diesel blends are the fuels to be burned in an experimental test burner manufactured for this reason in the laboratory scale.

The combustion is performed in air and by increasing the oxygen percentage gradually in order to investigate the results.

It was observed that by increasing the oxygen rate in the air from $21 \%$ to $28 \%$ by volume gradually, the flame length and the cone angle reduced by about $12 \%, 13.7 \%$ respectively in the case of $100 \%$ diesel fuel, and by $12.8 \%, 17 \%$ respectively in the case of $40 \%$ bio-diesel, Also the carbon monoxide "CO" and the unburned hydrocarbons in the exhaust reduced by $43 \%, 18 \%$ respectively in the case of $100 \%$ diesel fuel and by $54 \%, 42 \%$ respectively in the case of $40 \%$ bio-diesel but the temperature increased and as a result the NOx emissions increased as NOx is a temperature dependant.
It is observed that by increasing the oxygen rate the NOx emissions increased by $47 \%$ for diesel and by $65 \%$ for $40 \%$ bio-diesel.

The carbon dioxide and the gleam of the flame also increased by increasing the oxygen rate. By increasing the biodiesel amount in the blends from B0 to B40 the unburned hydrocarbons and carbon monoxide decreased by $68 \%$ and $30 \%$ respectively at $21 \%$ oxygen. So the combustion generally was improved however the temperature decreased as a result for the calorific value difference.

Bio-fuels have been used in conventional diesel and gasoline engines either as neat fuels or as supplements. By using oxy fuel combustion of renewable sources we can save money spent in conventional petroleum fuel.

Acknowledgment:-

The authors gratefully acknowledge the financial support officers from the office of the Tanta University Research Fund.

This work was supported by Tanta University Research Fund under the research grant (code: codtu,03-15-02). 


\section{REFERENCES:-}

[1]. N. Juradoa, H.G.D., E. J. Anthonya, J. E. Oakeya*, Oxy-combustion studies into the co -firing of coal and biomass blends: effects on heat transfer, gas and ash compositions. by Elsevier, 2014: p. 13.

[2]. J. Riaza, M.V.G., L. Álvarez, C. Pevida, J.J. Pis, F. Rubiera*, Oxy-fuel combustion of coal and biomass blends. Elsevier Ltd., 2012: p. 7.

[3]. Gerard Hillion (1), B.D., Dominique le Pennec (1), Laurent Bournay (1), JeanAlain Chodorge (2), BIODIESEL PRODUCTION BY A CONTINUOUS PROCESS USING A HETEROGENEOUS CATALYST. 2003: p. 3.

[4]. M. Sami, K.A., Co-firing of coal and biomass fuel blends, in Department of Mechanical Engineering2001, Texas A \& M University. p. 44.

[5]. Ignacio Trabadelaa*, H.C., Jon Gibbinsa, Oxy-biomass ignition in air and relevant oxy-combustion atmospheres for safe primary recycle and oxy-burner development. Elsevier Ltd., 2014: p. 12.

[6]. Wall T., L.Y., Spero C., Elliott L., Khare S., Rathnam R., Zeenathal F., Moghtaderi B., Buhre B., Sheng C., Gupta R., Yamada T., Makino K., Yu J., , An overview on oxyfuel coal combustion. 2009.

[7]. H. Chalmersc, M.A.-J., B. Anthonyb, S. Balusamya, S. Blackf, F. Cavallo, OxyCAP UK: Oxyfuel Combustion Academic Programme for the UK. Sciencedirect Elsevier Ltd., 2014: p. 7.

[8]. J. Riaza, L.Á., M.V. Gil, C. Pevida, J.J. Pis, F. Rubiera*, Effect of oxy-fuel combustion with steam addition on coal ignition and burnout in an entrained flow reactor. Elsevier Ltd., 2011: p. 6.

[9]. JB., H., Internal combustion engine fundamentals, . McGraw Hill International Edition. 1988.

[10]. Arafat A. Bhuiyan a, b., Aaron S. Blicblau a, Jamal Naser, Co-firing of biomass and slagging in industrial furnace: A review on modelling approach. by Elsevier Ltd., 2016: p. 17.

[11]. Montagne, X., European Motor Biofuels Forum. September 1996.

[12]. G. Hillion, X.M., P. Marchand, Oléagineux., Corps gras. Lipides.,. 1999. 6: p. 435.

[13]. Ms_JOBARI_, Investigation of the Spray and Flame Structure Characteristics of Jatropha Biodiesel Using Simplex Airblast Atomizer. p. 10.
[14]. (C) Fives North American Combustion, I., Burner Types and Applications. 2012: p. 76.

[15]. Baukal, C.E., Industrial Burners Handbook2004: CRC Press. 790.

[16]. Alejandro Sáez a, A.F.-M.b., Mario Toledo a, ${ }^{*}$, Liquid butane as an alternative fuel for diesel oil burners. Elsevier Ltd., 2012: p. 8.

[17]. Halina Pawlak-Kruczek*, M.O., Marcin Baranowski, Michał Czerep, Jacek Zgóra, CO-FIRING OF BIOMASS WITH PULVERISED COAL IN OXYGEN ENRICHED ATMOSPHERE. 2013: p. 12.

[18]. Mohd Hafidzal Hanafi, M.R.I., Mohd Azman Abdullah, Analysis Opacity and Size of Soot Particles in Fuel of Diesel Engine, 2015. p. 672-677.

[19]. Jonathan Audish, B.K., Edward Ma, Travis McDaniel, ACTIVE DIESEL SOOT MEASUREMENT BY LASER OPACITY, 2012. p. 43.

\section{APPENDIX:-}

Air to fuel ratio is used to calculate the needed amount of air for stoichiometric combustion in each case, and then the oxygen rate supplied to the reaction is known (21\%oxygen by volume is contented in air). This oxygen ratio is increased gradually with the added oxygen from $\mathrm{O} 2$ cylinder and the change of emissions and flame characteristics is studied.

Chemical equilibrium calculations:-

(Blend 0):-

The chemical formula for diesel fuel is: C7 H16.

We can get the air quantity needed for complete combustion between air and diesel fuel (stoichiometric) from the following equation. $\mathrm{C} 7 \mathrm{H} 16+\mathrm{a}(\mathrm{O} 2+3.76 \mathrm{~N} 2)--\mathrm{BCO} 2+\mathrm{C} \mathrm{H} 2 \mathrm{O}+\mathrm{D} \mathrm{N} 2$

By making a chemical balancing between the right and the left part, the chemical reaction equation will be:-

$\mathrm{C} 7 \mathrm{H} 16+11(\mathrm{O} 2+3.76 \mathrm{~N} 2)--7 \mathrm{CO} 2+8 \mathrm{H} 2 \mathrm{O}+41.4 \mathrm{~N} 2$ 
Calculating the air to fuel ratio:-

When:

$$
\mathrm{A} / \mathrm{F}=\frac{\text { Nair } * \text { Mw air }}{\text { Nfuel } * \text { Mw fuel }}
$$

Nair: the number of moles of air.

Nfuel: the number of moles of diesel fuel.

So:

$$
\mathrm{A} / \mathrm{F}=\frac{(11) *(4.76) *(29)}{1 *(7 * 12+16 * 1)}
$$

$\mathrm{A} / \mathrm{F}=15.18 \mathrm{Kgair} /$ Kgfuel

(B10):-

The (B10) fuel blend consists of 90\%diesel fuel mixing with $10 \%$ bio-diesel.

$0.9 \mathrm{C} 7 \mathrm{H} 16+0.1 \mathrm{C} 5 \mathrm{H} 10 \mathrm{O} 2+\mathrm{a}(\mathrm{O} 2+3.76 \mathrm{~N} 2)--$

$\mathrm{XCO} 2+\mathrm{Y} \mathrm{H} 2 \mathrm{O}+\mathrm{Z} \mathrm{N} 2$

By making balance for reactants and products/ $0.9 \mathrm{C} 7 \mathrm{H} 16+0.1 \mathrm{C} 5 \mathrm{H} 10 \mathrm{O} 2+10.3(\mathrm{O} 2+3.76 \mathrm{~N} 2)$ $6.8 \mathrm{CO} 2+7.2 \mathrm{H} 2 \mathrm{O}+38.7 \mathrm{~N} 2$

$\mathrm{A} / \mathrm{F}=\mathrm{m}$. air $/ \mathrm{m}$.fuel

$\frac{\mathrm{A}}{\mathrm{F}}=\frac{(10.3 * 4.76 * 29)}{(0.9 * 7 * 12+0.9 * 16)+(0.1 * 5 * 12+0.1 * 10+0.1 * 2 * 16)}$

$$
=14.18 \mathrm{Kga} / \mathrm{Kgf}
$$

(Blend 20):-

The (B20) fuel blend consists of $80 \%$ diesel fuel mixing with $20 \%$ bio-diesel.

$0.8 \mathrm{C} 7 \mathrm{H} 16+0.2 \mathrm{C} 5 \mathrm{H} 10 \mathrm{O} 2+\mathrm{a}(\mathrm{O} 2+3.76 \mathrm{~N} 2)--\mathrm{X}$

$\mathrm{CO} 2+\mathrm{Y} \mathrm{H} 2 \mathrm{O}+\mathrm{Z} \mathrm{N} 2$

By making balance for reactants and products/ $0.8 \mathrm{C} 7 \mathrm{H} 16+0.2 \mathrm{C} 5 \mathrm{H} 10 \mathrm{O} 2+10.1(\mathrm{O} 2+3.76 \mathrm{~N} 2)-$ $6.6 \mathrm{CO} 2+7.4 \mathrm{H} 2 \mathrm{O}+37.79 \mathrm{~N} 2$

$\mathrm{A} / \mathrm{F}=\mathrm{m}$. air $/ \mathrm{m}$.fuel

$\frac{\mathrm{A}}{\mathrm{F}}=\frac{(10.1 * 4.76 * 29)}{(0.8 * 7 * 12+0.8 * 16 * 1)+(0.2 * 5 * 12+0.2 * 10+0.2 * 2 * 16)}$

$$
=13.88 \mathrm{Kga} / \mathrm{Kgf}
$$

(Blend 40):-

The (B40) fuel blend consists of $60 \%$ diesel fuel mixing with $40 \%$ bio-diesel.

$0.6 \mathrm{C} 7 \mathrm{H} 16+0.4 \mathrm{C} 5 \mathrm{H} 10 \mathrm{O} 2+\mathrm{a}(\mathrm{O} 2+3.76 \mathrm{~N} 2)--\mathrm{X}$

$\mathrm{CO} 2+\mathrm{YH} 2 \mathrm{O}+\mathrm{Z} \mathrm{N} 2$

By making balance for reactants and products/

$0.6 \mathrm{C} 7 \mathrm{H} 16+0.4 \mathrm{C} 5 \mathrm{H} 10 \mathrm{O} 2+9.2(\mathrm{O} 2+3.76 \mathrm{~N} 2)-$

$6.2 \mathrm{CO} 2+6.8 \mathrm{H} 2 \mathrm{O}+69.2 \mathrm{~N} 2$

$\mathrm{A} / \mathrm{F}=\mathrm{m}$. air/m.fuel

$\frac{\mathrm{A}}{\mathrm{F}}=\frac{(9.2 * 4.76 * 29)}{(0.6 * 7 * 12+0.6 * 16 * 1)+(0.4 * 5 * 12+0.4 * 10+0.4 * 2 * 16)}$

$=12.6 \mathrm{Kga} / \mathrm{Kg}$. 